\title{
RELATIONSHIP BETWEEN NASAL SEPTUM DEVIATION AND LOCALIZATION OF EPIPHARYNGITIS FROM VIEW POINT OF EXFOLIATIVE CYTOLOGY
}

$\mathrm{By}$

$\mathrm{Y}_{\text {ASUO IDE }}$

From the Department of Oto-Rhino-Laryngology, School of Medicine, Tokyo Medical and Dental University (Director: Prof. S. Horiguti)

In order to explore the relationship of the nasal septum deviation with the localization of epipharyngitis, observation was made on the difference in the cytologic picture of epipharyngeal mucosa and in some clinical symptoms between right and left side in 160 cases of nasal septum deviation of various degrees. The results obtained are as follows.

1) With the increase of deviation the nasal obstruction became stronger on the convex than on the concave side, and situation was same for the pain on touch of the applicator with the epipharyngeal mucosa.

2) The exfoliation of ciliated epithelial cells was of a higher degree in the epipharyngeal mucosa to the convex side as compared with that to the concave side, and also the degree of their deformation was higher on the convex side in majority of the cases.

3) In not a few cases there were remarkable appearances of goblet cells, leukocytes and lymphocytes in the epipharyngeal mucosa to the convex side.

4) The foregoing findings seem to indicate that the epipharyngeal inflammation in the nasal septum deviation is rather strong in the region to the convex side of deviation.

\section{剝離細胞像よりみた鼻咽腔炎の 局在性と鼻中隔彎曲}

東京医科齿科大学耳鼻咽㬋科学教室（主任：堀口白作教授）

$$
\text { 范出 靖 夫 }
$$

目次

1.まえがき

I. 研究対象

II. 研究方法

1. 検査物の採取

2. 染色 法

IV. 研宛成組

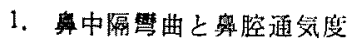

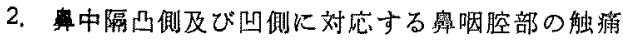
の比較

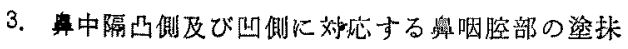
細胞像の比較 i 繁曲のない場合（正常）

ii 噶曲のある場合

（1）楾毛上皮科胞

(イ) 䟝 離 度

（口）細胞質の染色性

（八）細胞質の膨化

（二）線毛及び小皮緑

(木) 变形积度

（2）甭 細 胞

（3）扁平上皮緗胞

（4）白血球扣よびリンハ球

V 総括と孝按 
V. 結馀

参若交献

\section{I、まえがき}

鼻咽腔の㷋症 Epipharyngitis が耳鼻咽啹科領域の各 方面に種々なる影響を与えていることは，すでに多くの 臨床的観察により周知の事実である。しかしながら，奥 咽腔炎の現わす諸证状は更に厇範囲にわたるむのであつ

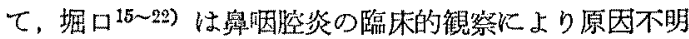
の諸種疾患，例之ば原因不明の頭痛，微熱，アレルギー 性番炎，習憒性アフタ性口内炎，立ちくらみ，小児の起 立性調節障害，口イマ，喘息などと密接な関係があるこ とを指摘し，稷咽腔の治療によりそれら諸症状が取除か れることを論述している。

しかるに，番咽腔の臨床的観察は，一般の方法では甚 しく困難であつて，從来は僅か後鼻鏡，鼻咽腔鏡等に よつて，その一部をうかがい知る程度であり，従つて蹦 林的に鼻咽腔炎を镜察する方法は極めて幼雅であり，そ れが従来鼻咽腔炎炕関する研究の行われなからた理由で あるとる考えられる。

さき教室の村上 ${ }^{2)}$ は，この舆咽腔上りの塗抹細胞 材料により，急性及び慢性時の種々線毛上皮像について 検索して好結果を得ている，その後，斎藤引は鼻咽腔 炎の治瘾過程を，臨床的並び㔀離細胞学的に追求乙 て，両者がよく平行関保を示すことを報告し，更に著者 ら1は，巻蟐子による鼻咽腔触痛之塗抹細胞像との間に 密接な関保があることを明かにした。 このように塗抹材 料に上る検索は，今まで盲点とされていた悬咽腔病変を 観察する一つの有力な手段であることが炊第に明がさ れてきた。

今回ここに，当教室に括ける 鼻咽腔研究の一端とし $\tau$ ，鼻中隔䇾曲の症例化つき，鼻咽腔上り左右別々汇塗 抹標本を作製して，これを剝離細胞学的激察し，臨床 症状と比較検討して與味ある知見を得たので報告する。

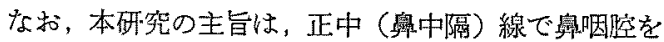
二つ分け，鼻咽院病变の左右差飞ついて述べるもので あるが，その目的は，あくまで舅咽腔病留の钼察に，よ り客倠性を与えようとするものである。

\section{II. 研究対象}

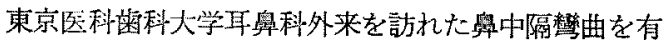
する患者 160 例で，症例はできるだけ初診時のものを撰 んだ、な特，鼻中隔繁尚を有するるのであ鼻腔の広さに 左右差のないものは除外した。

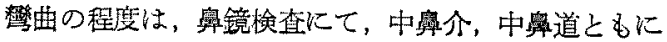

よく見えるものを正常とし，中稛道が見難く線状をなす むのを軽度，中鼻介の見光ないものを高度とし，その中 閒の中鼻介の一部が 見えるるのを中等度とした，突起 （に近いもの）に関しては，正中線より下鼻介前方の起 始部までの距離を 3 分し，その内 $1 / 3$ 以内にあるむのを 軽度，中 $1 / 3$ 以内にあるむのを中等度に，外 $1 / 3$ 沉ある ものを高度とした5).

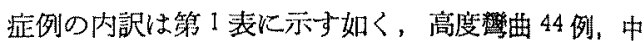

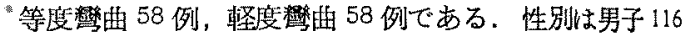
例，女子 44 例. 年令分布は 5 戈〜71 才に及んでいる。

第 1 表 番中隔禁曲症例

\begin{tabular}{|c|c|c|c|c|}
\hline & 例 数 & 男 & 女 & 年命分有 \\
\hline 高 度 鸺 曲 & 44 & 31 & 13 & $10 \sim 71$ \\
\hline 中等度第曲 & 58 & 45 & 13 & $5 \sim 74$ \\
\hline 軽 度 照曲 & 58 & 40 & 18 & $14 \sim 64$ \\
\hline 訫 & 160 & 116 & 44 & \\
\hline
\end{tabular}

\section{III. 研究方法}

1. 検查物の採取

正中（鼻中隔）線で鼻咽腔を二つに分け，鼻孔より左 右別々に鼻用巻綿子を插入乙，なるべく他の部に触れるる ようにして鼻咽腔に達し，その底（軟口蓋背面）に拈い て粘膜表面を軽く擦過し，左在別炕載物グラスに塰布， 直ちにェーテル・アルコール固定を行つた。

2. 染色法

Pharr の Papanicolaou 染色変法によつた.

IV. 研究成樍

\section{1. 鼻中隔弶曲と鼻腔通気度}

キリフンの奥息鏡（金属板に目盛の付してあるもの） を上口唇の高さで水平に，番腔の下にお学，鼻腔より一 度呼息を行い，2つの乎吸斑を得，その呼吸斑の消失時 間を測定して，番腔通気度を量的に比較し，それに被検

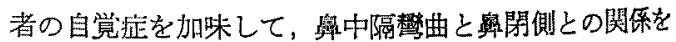
調ベた。

第 2 表から明らかなように，高度唫曲（以下高禁）で は凸側通気障害の高度のものが 33 例 $(75.0 \%)$ ，両湖 同程度だつたものが 11 例 $(25.0 \%)$ で，凹側倍高度だ つたものはなかつた，繇曲が軽度になるに従い，通棸障 害が両側同程度のもの及び凹儧䎲扰いて高度のものが增

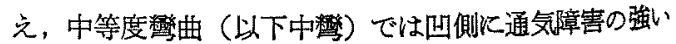

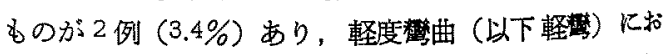
いては両側同程度（楀開のないと思われるむのむ含まれ 
る)であつたるのが43 例 $(74.1 \%)$ となつている.す

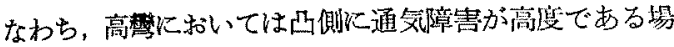

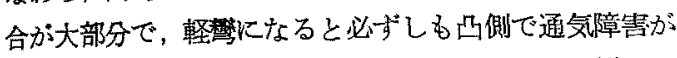
高度とは限らず，両側同程度のものが堌加し，中矪では その中閏にあたることが解る。

第 2 表 中隔凸側および凸側の奥閉の比較

\begin{tabular}{|c|c|c|c|c|c|c|c|c|c|}
\hline & \multicolumn{3}{|c|}{ 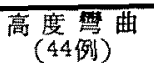 } & \multicolumn{3}{|c|}{$\begin{array}{c}\text { 中等度栔地 } \\
\text { (58例) }\end{array}$} & \multicolumn{3}{|c|}{ 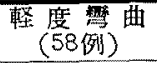 } \\
\hline 俳 & $\begin{array}{c}\mathrm{H} \\
\mathrm{H} \\
\mathrm{H}\end{array}$ & $t$ & $\frac{1}{2}$ & $\begin{array}{l}\text { H } \\
+ \\
\end{array}$ & + & $\frac{ \pm}{2}$ & $\begin{array}{l}H \\
\text { H } \\
+\end{array}$ & + & $\frac{1}{1}$ \\
\hline$\sim H$ & 0 & 0 & 0 & 1 & 1 & 0 & 2 & 0 & 1 \\
\hline$t$ & 16 & 5 & 0 & 13 & 8 & 1 & 6 & 16 & 0 \\
\hline$\pm \sim-$ & 10 & 7 & 6 & 6 & 14 & 14 & 1 & 7 & 25 \\
\hline 棓 & 26 & 12 & 6 & 20 & 23 & 15 & 9 & 23 & 26 \\
\hline
\end{tabular}

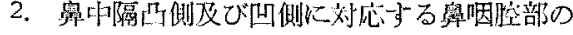
角触痛の比慗

鼻咽腔に炎症が存代方る时，その粘膜表面を卷綿子に て擦過すると，激しい疼痛（これを触浦と呼ぶ）を挀 兑，しばしぱその部から出血を見ることさえある。この 触痛の程度を高度〜中等度 $(H+H)$, 俥圣度 $(t)$, 極整 度 (土)，無し（一）上4段階に区分して，闰一症例に

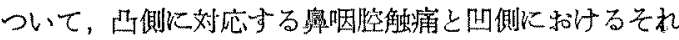
とを比較した（第3 表).

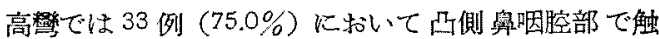
痛がより激しく，その中で触痛が著差（例えば凹側で州 〜H，四側で士というような例）と思われるすのが19 例で全体の $43.2 \%$ K当る．雨側同程度であつたすの11 例 $(25.0 \%)$ ，四側舆咽腔部で触湍がより激しかかたもの は一・例名ない

第3 表 中隔凸側和よび凹僛舆咽腔の触痛の比較

\begin{tabular}{|c|c|c|c|c|c|c|c|c|c|c|c|c|}
\hline & \multicolumn{4}{|c|}{ 高度檺曲（44例） } & \multicolumn{4}{|c|}{ 中等度繁曲 (58例) } & \multicolumn{4}{|c|}{ 整度整曲（58例） } \\
\hline 巴俳 & $|H \sim H|$ & + & \pm & - & $|H \sim H|$ & + & \pm & - & $|H \sim H|$ & $t$ & \pm & - \\
\hline$H \sim H$ & 1 & 0 & 0 & 0 & 3 & 2 & 0 & 0 & 1 & 7 & 1 & 1 \\
\hline+ & 19 & 8 & 0 & 0 & 21 & 10 & 2 & 0 & 15 & 8 & 2 & 0 \\
\hline \pm & 6 & 6 & 1 & 0 & 4 & 2 & 5 & 0 & 1 & 5 & 8 & 0 \\
\hline- & 0 & 1 & 1 & 1 & 1 & 4 & 1 & 3 & 2 & 5 & 0 & 2 \\
\hline 計 & 26 & 15 & 2 & 1 & 29 & 18 & 8 & 3 & 19 & 25 & 11 & 3 \\
\hline
\end{tabular}

中警では，凹側鼻咽腔部で触痛が強かつたもの33例 $(56.9 \%)$ ，両僋同程度であつたもの 21 例 (36.2\%)，讪 側で触痛が強かつた6の4 例 $(6.9 \%)$ ，軽急では，凹側

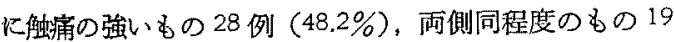
例 $(32.8 \%)$ ， 凹側に触痛の強い屯の11 例 $(19.0 \%) て$ ある.

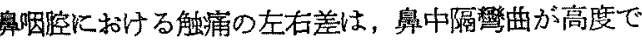
ある時は，その凸側部でより著しくなる攧向がある。慗 曲が軽度になるに徒つてこの傾向は少くなり，中

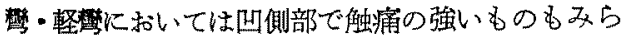
れるよらになる。

又触痛が湤しくなると，巻綿子小接触以より，鼻 咽腔より出血の見られることがしばしばあつた。

3. 鼻中隔凸側及び凹側に対応する 鮙咽膑部の塗枺細胞像の比較

i 禁曲のない場合 (正常)

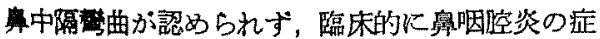

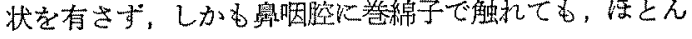

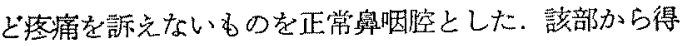

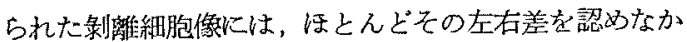
st.

すなわら，㔀離されてくる線毛上皮細胞の数は極めて 少く，これがうすい粘液の中に点在してみられる。その 他には，ごく少数の白血球，リンパ球，辟平上皮細胞が 混在し，稀に盃細胞の認められることがある。

第 1 図正常線毛上皮細胞像（村上による）

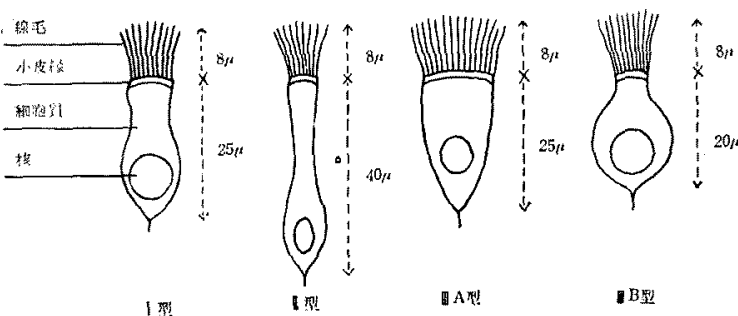


線毛上皮細胞は多数の線毛を有して和り，細胞輸崕は 明膫で，細胞罂，核の染色状態も良好である，その形態 は教室の村上2）の分類従之ば（第１図），I型（普通 型）が大部分で，【型 (細長型)，四型 (二等迅三角形 型及び樽型）が低い出現率でこれ混ずる。

\section{ii 㴔曲のある場合}

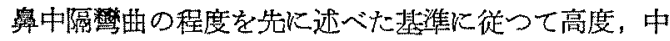
等度、軽度の3群に分け，それぞれの群について，中隔 凹側及び凹側に対応した系咽腔部の塗玬細胞像儿つき比 較した。

\section{（1）線毛上皮細胞}

(イ）剶 離 度

塗抹標本上に現われる線毛上皮細胞の剝離度につ、 て, 顕微鏡下 100 倍抎大視野にて, 平均してすべての視 野に多くの線毛細胞のみられるるのを極高度とし, 全視 野に10ヶ内外以下のわのを極轻度となし，その間を高 度，中等度，軽度に区分して，線毛細胞自身の变形程度 には関係なく観察した結果を第 4 表に示した。

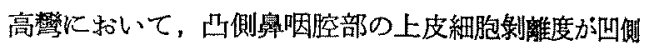
のそれより高度であつたもの 38 例 (86.4\%)，雨側同程

第 4 表 中隔凸側和よび凹側鼻咽腔の線毛上皮細胞㔀離度の此較

\begin{tabular}{|c|c|c|c|c|c|c|c|c|c|c|c|c|c|c|c|}
\hline & \multicolumn{5}{|c|}{ 高 度 零 曲 (44例) } & \multicolumn{5}{|c|}{ 中等 度 繁 曲 (58例) } & \multicolumn{5}{|c|}{ 整 度 繁 曲 (58例) } \\
\hline 凹㑡 & $\begin{array}{l}\text { 極 } \\
\text { 高 } \\
\text { 度 }\end{array}$ & $\begin{array}{l}\text { 高 } \\
\text { 度 }\end{array}$ & $\begin{array}{l}\text { 中 } \\
\text { 等 } \\
\text { 紋 }\end{array}$ & $\begin{array}{l}\text { 軽 } \\
\text { 度 }\end{array}$ & $\begin{array}{l}\text { 極 } \\
\text { 柽 } \\
\text { 度 }\end{array}$ & $\begin{array}{l}\text { 極 } \\
\text { 高 } \\
\text { 度 }\end{array}$ & $\begin{array}{l}\text { 高 } \\
\text { 度 }\end{array}$ & $\begin{array}{l}\text { 中 } \\
\text { 等 } \\
\text { 度 }\end{array}$ & $\begin{array}{l}\text { 崩 } \\
\text { 度 }\end{array}$ & $\begin{array}{l}\text { 㯟 } \\
\text { 等 } \\
\end{array}$ & 極 & $\begin{array}{l}\text { 高 } \\
\text { 度 }\end{array}$ & $\begin{array}{l}\text { 中 } \\
\text { 等 } \\
\text { 度 }\end{array}$ & $\begin{array}{l}\text { 释 } \\
\text { 度 }\end{array}$ & $\begin{array}{l}\text { 霓 } \\
\text { 度 }\end{array}$ \\
\hline 極高度 & 0 & 0 & 1 & 0 & 0 & 0 & 2 & 0 & 0 & 0 & 0 & 1 & 0 & 0 & 0 \\
\hline 高度 & 0 & 1 & 0 & 0 & 0 & 0 & 1 & 3 & 1 & 1 & 0 & 1 & 2 & 2 & 1 \\
\hline 中等度 & 0 & 7 & 2 & 0 & 1 & 1 & 8 & 4 & 2 & 1 & 0 & 8 & 8 & 6 & 0 \\
\hline 軽 度 & 1 & 9 & 5 & 1 & 0 & 0 & 5 & 7 & 7 & 3 & 0 & 3 & 2 & 9 & 1 \\
\hline 極轻度 & 0 & 7 & 7 & 2 & 0 & 0 & 1 & 7 & 4 & 0 & 0 & 1 & 3 & 9 & 1 \\
\hline 計 & 1 & 24 & 15 & 3 & 1 & 1 & 17 & 21 & 14 & 5 & 0 & 14 & 15 & 26 & 3 \\
\hline
\end{tabular}

度であつたもの 4 例 $(9.1 \%)$ ，凹側で上皮細胞剝離度が 高度だつたものが 2 例 (4.5\%) であつた。

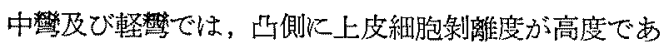
つたものは，それぞれ33 例 $(56.9 \%)$ と 26 例 (44.9\%)， 同程度たつたものは，12 例 $(20.7 \%)$ と 19 例 (32.8\%),

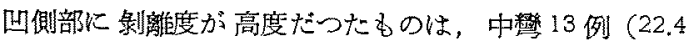
$\%$ ，軽䇣13例 (22.4\%) であった。

また凸側鼻咽腔部において，その剥離度差が大きく2 段階差（例党ば凹側部で高度，凹側部で軽度）以上であ つたものは，高彎では 24 例 $(54,5 \%)$ ，中彎では 13 例 $(22.4 \%)$ ，整彎で虫7 例 $(12.1 \%)$ であつた。

全般的にみて，彎曲が高度のるの程，凹側鼻咽腔部に 扰いての上皮細胞剝離度が高く，その剝離度差子他側仡 此して著しい、第曲が軽度になるに従い，剥離度差の著 しいものは少くなり，両側同程度のもの，及び凹側部に 䟝離度の高いるのが多くみられる上らになる(しかし 35\% 以上には達しない).

（口）細胞質の染色性

正常な線毛上皮細胞は，Eosinによく染まる紐胞質を 有しているが，細胞質の膨化，空胞化などがみられる時
は，細胞貿の染色性は不良となる，染色性の度合は，染 色液の状態乞の他の条件で，かなり左右されるものであ

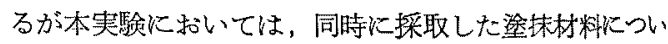
て，固定時間及び染色液の状熊を同じ条件见しているの で線毛上皮の細胞質の染色度合について，同一症例の左 右差を比較することは可能であると思う．

細胞質の染色度合を良好，中等度，不良に区分し，一 括して示すと第 5 表の如くなる.な拈，片側鼻咽院て線 毛上皮細胞が，汪とんど䟝離されてこなからた6 6 例（高

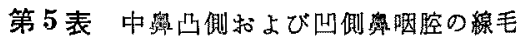
上皮細胞の細胞賀染色性の比較

\begin{tabular}{|c|c|c|c|c|c|c|c|c|c|}
\hline & \multicolumn{3}{|c|}{$\begin{array}{c}\text { 高度想西 } \\
(41 \text { 例) }\end{array}$} & \multicolumn{3}{|c|}{$\begin{array}{c}\text { 中等度燢曲 } \\
\text { (56例) }\end{array}$} & \multicolumn{3}{|c|}{$\begin{array}{c}\text { 整度管西 } \\
\text { (57 例) }\end{array}$} \\
\hline 凸側 & $\begin{array}{l}\text { 良 } \\
\text { 好 }\end{array}$ & $\begin{array}{l}\text { 中 } \\
\text { 等 } \\
\text { 度 }\end{array}$ & $\begin{array}{l}\text { 不 } \\
\text { 良 }\end{array}$ & $\begin{array}{l}\text { 良 } \\
\text { 好 }\end{array}$ & $\begin{array}{l}\text { 中 } \\
\text { 等 } \\
\text { 度 }\end{array}$ & $\begin{array}{l}\text { 不 } \\
\text { 良 }\end{array}$ & $\begin{array}{l}\text { 良 } \\
\text { 好 }\end{array}$ & $\begin{array}{l}\text { 中 } \\
\text { 等 } \\
\text { 度 }\end{array}$ & 不 \\
\hline 好 & 7 & 9 & 1 & 6 & 9 & 0 & 11 & 5 & 1 \\
\hline 中 等 度 & 1 & 15 & 4 & 1 & 24 & 4 & 1 & 17 & 7 \\
\hline 良 & 0 & 0 & 4 & 0 & 0 & 12 & 1 & 2 & 12 \\
\hline 計 & 8 & 24 & 9 & 7 & 33 & 16 & 13 & 24 & 20 \\
\hline
\end{tabular}




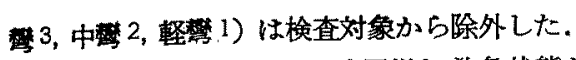

両側卧明腔部ともに，活ぼ同様な染色状態を示した

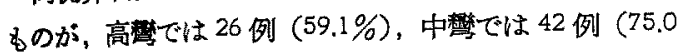
$\%$ ，軽禁では 40 例 $(70.2 \%)$ と，ほとんど大部分を占 めているが，高禁に和いては，その占める比率が中鸺，

軽场に比して低い，凸側鼻咽腔部が凹側上り不良の染 色性を示したるのは，それぞれ14例 $(34.1 \%) ， 13$ 例 $(23.2 \%) ， 13$ 例 (22.8\%) であつて，凸側部で染色性が

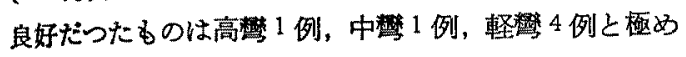
て少小.

すなから，線毛上皮の細胞質の染色状態は，両側同程 度のbのが大部分であるが，そうでない場合には，凸側 部の方が他側比して，不良であるものが多く，その此 率は清が高度となるにつれて大きくなる。

（ハ）細胞質の膨化

細胞質の膨化状態を高度, 中等度, 軽度〜正常の 3 群 に分けた．䁗化が高度なものは，村上のいら【型あるい は目型の形態を示するのは極めて少く，細胞質の膨化と るに、細胞の形は四型に類似するようになり、細胞の輪 䂙も不鮮明になつてくるるのが多い，種々の程度の变化 が見られる場合には，その中で最る頻度の高いるのをる つて記載した。 な和前項同様，片側鼻咽腔部で線毛上皮 細胞がほとんど㓡離されてこなかつた6例は除いた。

第6表から明らかのように，中隔凸側鼻咽腔部におい て，膨化程度が凹側のそれより著しかつたものは高禁 11 例 $(26.8 \%)$ ，中禁 12 例 $(21.4 \%)$ ，軖䇾 10 例 (17.5 \%)であり，両側同程度であつたものは，それぞれ28 例 $(68.3 \%), 40$ 例 (71.4\%)，43例 (75.4\%) であつた。 また凹側部の方が膨化の著しかつたものは高繁で 2 例 $(4.9 \%)$ ，中禁で 4 例 $(7.1 \%)$ ，軽慗で 4 例 $(7.1 \%) 2$ み れた.

第6表 中隔凸側および凹側鼻咽腔の線毛 上皮の細胞質膨化程度の比較

\begin{tabular}{|c|c|c|c|c|c|c|c|c|c|}
\hline & \multicolumn{3}{|c|}{ 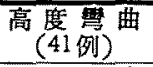 } & \multicolumn{3}{|c|}{$\begin{array}{c}\text { 中等度攀曲 } \\
(56 \text { 例) }\end{array}$} & \multicolumn{3}{|c|}{$\begin{array}{c}\text { 俥圣度蓜曲 } \\
\text { (57 例) }\end{array}$} \\
\hline 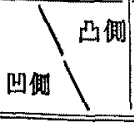 & $\begin{array}{l}\text { 高 } \\
\text { 度 }\end{array}$ & $\begin{array}{l}\text { 中 } \\
\text { 等 } \\
\text { 度 }\end{array}$ & $\begin{array}{l}\text { 整 } \\
\text { 正 } \\
\text { 管 }\end{array}$ & $\begin{array}{l}\text { 高 } \\
\text { 度 }\end{array}$ & $\begin{array}{l}\text { 中 } \\
\text { 等 } \\
\text { 度 }\end{array}$ & $\begin{array}{l}\text { 整 } \\
\text { 正 } \\
\text { 常 }\end{array}$ & $\begin{array}{l}\text { 高 } \\
\text { 度 }\end{array}$ & $\begin{array}{l}\text { 中 } \\
\text { 等 } \\
\text { 度 }\end{array}$ & $\begin{array}{l}\text { 整 } \\
\text { 正 } \\
\text { 常 } \\
\end{array}$ \\
\hline 度 & 1 & 0 & 0 & 3 & 0 & 1 & 2 & 0 & 0 \\
\hline 中 等 度 & 1 & 5 & 2 & 2 & 9 & 3 & 3 & 14 & 4 \\
\hline 軽 〜 正常 & 2 & 8 & 22 & 0 & 10 & 28 & 1 & 6 & 27 \\
\hline 矿 & 4 & 13 & 24 & 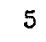 & 19 & 32 & 0 & 20 & 31 \\
\hline
\end{tabular}

線毛上皮の細胞質の膨化についても，両側覓咽腔とも 同程度であつたものが大部分であるが，そうでない場合 には，品側部の方が他側より著しいるのが多く，その比 率は高就で $26.8 \%$ と最も大きい。

\section{（二）線毛及び小皮緑}

線毛及び小皮縁については，その有無のみに着目し， 检鏡された線毛上皮細胞数の1/2 以上が線毛（小皮縁） を有する場合を十，1/2 以上が無線毛（無小皮縁）の場 合をーとし，その中間をさとして，その関係を第 7表， 第8表に示した。

第 7 表 中隔凸㑡および凹側奥咽䐋の 上皮細胞の線毛状態の比較

\begin{tabular}{|c|c|c|c|c|c|c|c|c|c|}
\hline & \multicolumn{3}{|c|}{$\begin{array}{c}\text { 高度麗曲 } \\
(41 \text { 例) }\end{array}$} & \multicolumn{3}{|c|}{ 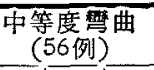 } & \multicolumn{3}{|c|}{$\begin{array}{c}\text { 軽度签曲 } \\
(57 \text { 例) }\end{array}$} \\
\hline 凹偩 & + & \pm & - & + & \pm & - & + & \pm & $\rightarrow$ \\
\hline+ & 2 & 2 & 4 & 5 & 1 & 5 & 4 & 2 & 0 \\
\hline \pm & 1 & 3 & 7 & 0 & 2 & 7 & 0 & 4 & 5 \\
\hline- & 0 & 1 & 21 & 0 & 3 & 33 & 0 & 3 & 39 \\
\hline 柿 & 3 & 6 & 32 & 5 & 6 & 45 & 4 & 9 & 44 \\
\hline
\end{tabular}

第 8 表中隔凸側および凹側鼻咽腔の 上皮細胞の小皮緑状態の比較

\begin{tabular}{|c|c|c|c|c|c|c|c|c|c|}
\hline & \multicolumn{3}{|c|}{$\begin{array}{c}\text { 高度㗫曲 } \\
(41 \text { 例) }\end{array}$} & \multicolumn{3}{|c|}{$\begin{array}{c}\text { 中等度憗曲 } \\
(56 \text { 例) }\end{array}$} & \multicolumn{3}{|c|}{$\begin{array}{c}\text { 軽度警豊 } \\
(57 \text { 例) }\end{array}$} \\
\hline 凹側 出側 & + & \pm & - & + & \pm & - & + & \pm & - \\
\hline+ & 22 & 7 & 1 & 22 & 6 & 5 & 25 & 5 & 4 \\
\hline \pm & 1 & 5 & 0 & 3 & 5 & 3 & 1 & 7 & 2 \\
\hline- & 1 & 0 & 4 & 0 & 2 & 10 & 1 & 1 & 11 \\
\hline 言1 & 24 & 12 & 5 & 25 & 13 & 18 & 27 & 13 & 17 \\
\hline
\end{tabular}

凸側鼻咽腔部で，より高度に線毛の脱落を認めたもの

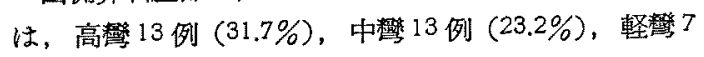
例 $(12.3 \%)$. 両側部とも注ぼ同程度であつたものは, それぞれ26例 $(63.4 \%) ， 40$ 例 $(71.4 \%) ， 47$ 例 $(82.5$ \%)であつた。 また山側部で脱落が著しからたるのは，

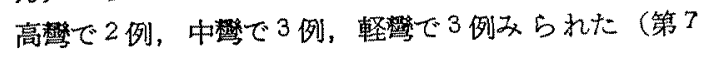
表).

線毛の脱落は，两側鼻咽腔部とも同程度のものが大半 を占めているが，それ以外の場合では，凸側部で脱落の 高度なるのが多い。

小皮縁の状態る，だいたい線毛の場合と同様な傾向が みられる(第8表)。 
（ホ）変形程度

ここに述べる線毛上皮細胞の変形とは，上述した (口)，（八)，（二）の項を総合したもので，上皮細胞の 変性といらことも加味されている。

細胞買の膨化が著しく，染色性は不良で細胞の形とし ては III型に類仪し，無線毛型に近く，細咆輸廓の不鮮明 なものを变形高度（付図写真 C を参照）とし，比較的

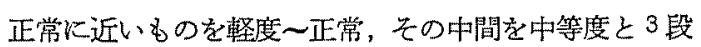
陵に区分して，その左右差を唉訪した（第9表）。

第 9 表 中隔凸側於よび凹側番咽腔の 線毛上皮細胞变形程度の比較

\begin{tabular}{|c|c|c|c|c|c|c|c|c|c|}
\hline & \multicolumn{3}{|c|}{ 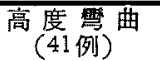 } & \multicolumn{3}{|c|}{$\begin{array}{c}\text { 中等度䇾㤟 } \\
(56 \text { 例) }\end{array}$} & \multicolumn{3}{|c|}{ 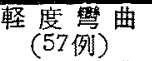 } \\
\hline 田側 & $\begin{array}{l}\text { 高 } \\
\text { 度 }\end{array}$ & $\begin{array}{l}\text { 中 } \\
\text { 等 } \\
\text { 度 }\end{array}$ & $\begin{array}{l}\text { 慗 } \\
\text { 焉 } \\
\text { 常 }\end{array}$ & 高 & $\begin{array}{l}\text { 中 } \\
\text { 等 } \\
\text { 度 }\end{array}$ & $\begin{array}{l}\text { 埾 } \\
\text { 正 } \\
\text { 常 }\end{array}$ & 高 & $\begin{array}{l}\text { 中 } \\
\text { 等 } \\
\text { 度 }\end{array}$ & $\frac{\text { 整 }}{\frac{1}{\text { 正 }}}$ \\
\hline 高 & 1 & 0 & 0 & 3 & 0 & 1 & 5 & 2 & 1 \\
\hline 中等 度 & 2 & 8 & 1 & 5 & 8 & 5 & 4 & 9 & 4 \\
\hline 軽 〜 正常 & 4 & 8 & 17 & 5 & 11 & 18 & 2 & 9 & 21 \\
\hline 訪 & 7 & 16 & 18 & 13 & 19 & 24 & 11 & 20 & 26 \\
\hline
\end{tabular}

線毛上皮細胞の変形が，両側鼻咽腔部之も同程度であ

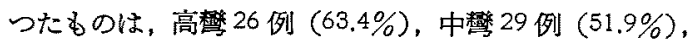
軽攀 35 例 $(61.4 \%)$ ，凸側部で変形が著しかつたものは， それそれ 14 例 (34.1\%)，21例 (37.5\%)，15例 (26.3 \%)であつた，凹側部で変形が著しかつたものが，高慗

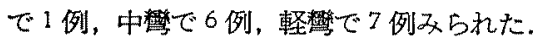

また亲形が「两側畺咽腔部ともに同程度」あるいは 「れ側部で変形が著しかつたもの」についてみると，高

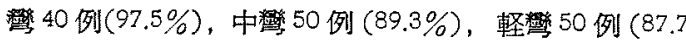
\%)となる。

線毛上皮細胞の変形程度は，慗曲が高度になる程，そ の凸側與咽腔部で，より著しいものが多くなる。

(2) 盃 細 胞

而細胞は前逝したように，正常では稀に出現するもの である. 正常よりやや多いものを十，多いものを圮 て，その出現数を舆㸶腔部の左右差について観察すると 第10妾の如くなる。

表から明かなよらに，全症例の半数近くが両側䊩胭腔

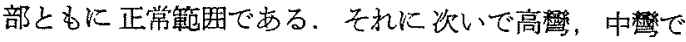
は，凸側部で出現の高いものが，それぞれ9例 (20.9 $\%$ ，13例 $(22.4 \%)$ と多いが，軽禁では凸側部に盃細 胞が多かつた例数と，凹側部に多からた例数との差が著
第 10 表 中隔凸側および凹側舜咽腔の 盃細胞の量的比較

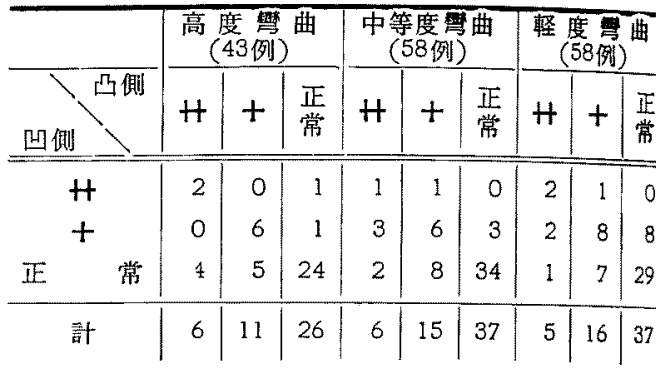

明でない。

(3) 扁平上皮細胞

扁平上皮細胞の出現は，両側鼻咽腔部之す同程度でま つたものが，高彎 32 例 (72.7\%)，中彎 44 例 (75.9\%)， 軽熱 43 例 $(74.1 \%)$ と多く，去れ以外の場合です，そ の左在差のばらつきが大きく，どちらかに多いといら保 向は認められない（第11表）。また，午の角化程度を見 分けるための, 染色の色調の左右差についても一定の既 保は得られなかつた。

第 11 表 中隔凸側および凹側鼻咽腔の 雇平上皮出現度の比较

\begin{tabular}{|c|c|c|c|c|c|c|c|c|c|}
\hline & \multicolumn{3}{|c|}{$\begin{array}{c}\text { 高度䇾曲 } \\
(44 \text { 例 })\end{array}$} & \multicolumn{3}{|c|}{$\begin{array}{c}\text { 中等度暍曲 } \\
(58 \text { 例) }\end{array}$} & \multicolumn{3}{|c|}{$\begin{array}{c}\text { 柽度量曹 } \\
(58 \text { 例) }\end{array}$} \\
\hline 뜨側 & $H$ & $t$ & 正 & $H$ & $t$ & 正 & $H$ & + & $\frac{\text { 正 }}{\text { 常 }}$ \\
\hline$H$ & 0 & 3 & 0 & 0 & 1 & 0 & 1 & 2 & 3 \\
\hline+ & 1 & 1 & 4 & 1 & 4 & 4 & 0 & 7 & 4 \\
\hline 正 & 1 & 3 & 31 & 2 & 6 & 40 & 2 & 4 & 35 \\
\hline 計 & 2 & 7 & 35 & 3 & 11 & 44 & 3 & 13 & 42 \\
\hline
\end{tabular}

（4）白血球及びリンパ球

白血球及びリンパ球の量については，涾抹部位全体に 平均して多数認めるすのを高度（H）とし，湮抹部位全 体に極少数 (以下) 認めるむのを正常として，この間 中等度 $(H)$, 軽度 $(+)$ に区分した.

白血球についての成績は，第12表に示す通りで，两 側鼠咽腔部之むに同程度の出現数を示したすのは，高靬 17 例 (38.6\%)，中慗 24 例 $(41.4 \%)$ ，軽繁 23 例 (39.7 \%)で，その中正常群に属するものが，それそれい例 $(13.6 \%), 12$ 例 (20.9\%)，12 例 (20.9\%) であつた. 凸側部で出現数の多からたものは高警 20 例 (45.5\%)，

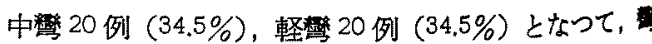




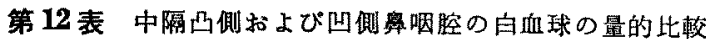

\begin{tabular}{|c|c|c|c|c|c|c|c|c|c|c|c|c|}
\hline & \multicolumn{4}{|c|}{ 高度禁曲（44例） } & \multicolumn{4}{|c|}{ 中等度謷曲 (58例) } & \multicolumn{4}{|c|}{ 軽度桴曲 (58例) } \\
\hline 凹側 呙䁚 & $H$ & $H$ & + & 正常 & $\mathrm{HH}$ & $H$ & + & 正常 & H & $H$ & + & 正常 \\
\hline$H$ & 0 & 0 & 1 & 0 & 3 & 2 & 2 & 0 & 2 & 1 & I & 0 \\
\hline$H$ & 0 & 3 & 2 & 1 & 2 & 2 & 7 & 0 & 2 & 0 & 8 & 0 \\
\hline+ & 1 & 8 & 8 & 3 & 2 & 7 & 7 & 3 & 0 & 7 & 9 & 5 \\
\hline 正 & 1 & 3 & 7 & 6 & 0 & 1 & 8 & 12 & 0 & 4 & 7 & 12 \\
\hline it & 2 & 14 & 18 & 10 & 7 & 12 & 24 & 15 & 4 & 12 & 25 & 17 \\
\hline
\end{tabular}

第 13 表 中隔凸側および凹側鼻胭腔のリンパ球の量的比較

\begin{tabular}{|c|c|c|c|c|c|c|c|c|c|c|c|c|}
\hline & \multicolumn{4}{|c|}{ 高度漈曲（44例） } & \multicolumn{4}{|c|}{ 中等度慧曲 (58例) } & \multicolumn{4}{|c|}{ 軽度概曲（58例） } \\
\hline 出側 品側 & Ht & $H$ & $t$ & 正常 & Ht & $H$ & + & 正常 & HH & H & + & 正常 \\
\hline$H$ & 0 & 0 & 0 & 0 & 0 & 0 & 0 & 0 & 0 & 0 & 0 & 0 \\
\hline$H$ & 1 & 2 & 0 & 0 & 1 & 5 & 3 & 1 & 0 & 4 & 1 & 1 \\
\hline+ & 1 & 3 & 10 & 2 & 0 & 4 & 10 & 5 & 0 & 1 & 15 & 4 \\
\hline 正常 & 0 & 1 & 11 & 13 & 0 & 1 & 10 & 18 & 0 & 2 & 6 & 24 \\
\hline 計 & 2 & 6 & 21 & 15 & 1 & 10 & 23 & 24 & 0 & 7 & 22 & 29 \\
\hline
\end{tabular}

曲の高度の方が，凸側部で白血球の出現が著しいことが 解る. 四側部で出現数の多かつたものは, 高鉴 7 例, 中 鸺 14 例，軽埶 14 例で，禁曲が軽くなるとその例数が增 它傾向がある。

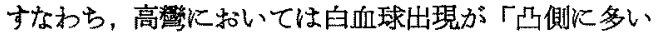
もの」が最も多く，次いで「両側同程度のもの」「凹側

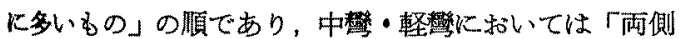
同程度のもの」「凸貸多いるの」「凹貸に多いるの」 の順炕なる。

リンパ球についても(第13表)，白血球と同じよ5な 傾向がみられたが，たた両側鼻咽腔部で，その出現数 が同程度であつたものが，高勢 25 例 (56.8\%)，中第 33 例 $(56.9 \%)$ ，軽度 43 例 $(74.1 \%)$ ， 白血球の場合の それに比して高率であり，更にその中で，正常群化属す るるのの比率も高くなる。

\section{V. 総括と考按}

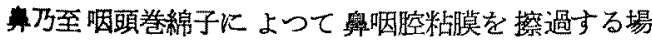
合そこに疼痛（触痛）ならびに出血を楒める時，同時 に採取した塗林材料（上皮像，遊走細胞像，細菌像な どょりここにこの症状と平行した急性乃至覀急性炎 を㷵めることができるといらことは，当教室の研究 1) 3）15 22）によつて明かにされた。すなわら，亩乃至明頭
巻綿子を夓咽腔に插入して，そこに擦過痛(触痛) が存 在する時は，ここに炎症が存在するということを考学う るものであるが，このことから臨床において，番胭腔粘 膜に和ける触痛ならびに出血等を指標として，こ机に合 わせて染抹摽本を観察する時は，䁷咽腔に特りる炎症の 状態をかなり客観的に察知することができる。

著者はこの方法を用いて，舆咽腔とくに軟口䀅背面 に和ける次症の局在性をしらべたのである、蓋し䁌楒 炎の原因の一つは，この部に括ける鼻内気流と密接な関 係があることは，臨㦿的見地等から一般に想像されると ころであるが，その究明のために，同一条件代ある同一 人を用いて，鼻内気流の左右差によつて鼻咽腔炎の局在 性がいかなる状態にあるかといらことを検討した。この

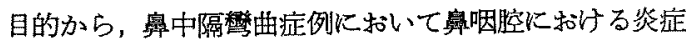
の局在状態を調べ, 焣に䁲腔の左右通気度との関係をし

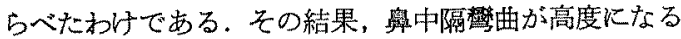
に従い，中隔几側に対する奥咽腔部に和いて，より激し

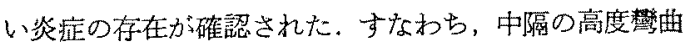
例に和いては，その大多数の症例に执いて凸側部の舆㸶 腔蚛樒が他側より激しく，乙かもその差の著しいるすが 多かつた，少数の例に和いて，触痛が闻側同程度のもの があつたが，少くとむこのよらな高度矮曲症例に数いて 


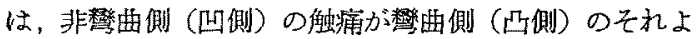
りも著しいという症例は一例もなからた。塗枺標本上の 細胞像もこれら触痛と平行して括り，線毛上皮細胞の剝 離数は非学曲側に比して，督曲側が著しく多く（炎症の 高度なもの程上皮細胞の剥離数が多い，これに応して

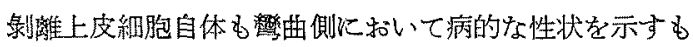
のが多からた。しかして，同じ高度桴曲群であってる， 䅓曲が高度になるに従つてこのよらな傾向は著しくな る、また，盃細胞，白血球，リンバ球など炎症と関連の ある細胞の出現も凸倒部に㕲いてより著しいことが証明 された。このような傾向は，中等度彎曲ならびに軽度禁

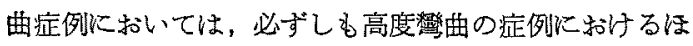
ど著しくはないがややり同様な䞶性が認められた。

これらの事実は，先の研究1でのべたことょり，鼻

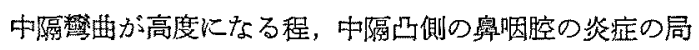
在性が著しいといらことを示唆するものである.

このよらな鼻咽腔に和ける桨定の局在性の原因につい ては，奥中隔数曲による片側通気障害といらことが重要 な因子上なつていることが教られる。このことは，研 究成績の項でのべてあるように（第 2 表，第3表参照)， 舅腔通気度の左右差と鼻咽腔触痛の左右差とが，ほぼ平 行関係を示すことから理解される.すなわち，敬曲が高 度になつて，彎曲側に打外る通気障害が著しくなる程， 警曲側 (凸側) に和ける鼻咽腔炎の局在性が強くなるの である.

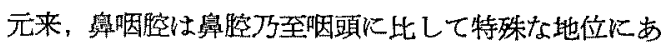
り，番腔内に吸込文九た空気，塵埃、細菌等は一時この 部で解放され，それから下方に向らるのであるが，片側 通気障害が存在する場合，吸込末れた空気が鼻中隔後端 において舅咽腔に解放される際，閉鎖側察咽腔部では， とくにその後鼻孔直後方部が隍圧となるため，扣そらく この部位に空気の洞流が発生し，一種の“ふきだまり” のような現象が起り，それに伴つて空気中の塵埃や細菌 等の附着が起りやすい状態を招来せしめるのであろう。 その結果，それらが刺激となつて跜在性の舅咽腔炎を意 起せしめるるのと思われる.すなわち，片側通気障害の

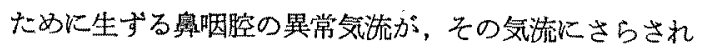
る粘膜上皮に资症性病変を招来世しめるため汇，この炎 症の局在性といらものが生じたと考劣ることができる。

線毛上皮が異常気流瀑露されると，上皮の性状が変 るであろうといらことは，かなり以前から推則されてい た。下鼻介先端は新生児では線毛上皮で被われている が，成人では扁平上皮で扣きかえられているという事実
(Proetz ${ }^{12)}$, Hilding ${ }^{10)}$, Schall ${ }^{13)}$, Schiefferdecker ${ }^{14)}$

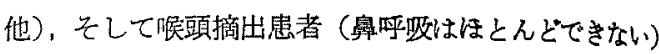
では，先机が再び線毛上皮で扣きか克られているといら Sternberg 8), Dixon ら9) の記載も，要する汇粘膜上皮 が異常気流爆露されるか否かということによつて左右 された結果だと考えることができるし，又片飤前鼻孔を 開じた動物では，その閉鎖側および非開鎖則の控粘膜 上皮に著しい差異が生ずるといら Hilding ${ }^{10)}$ の央験，

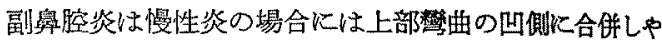
く，急性炎の場合は逆で莮腔の狭い万顕著な症状があ らわれやすいという高橋 (良) $)^{2 b)}$ の報告も，巽常気流が その原因となつていると考えられる。

早川 28) は動物で一側前鼻孔を閍じると，開鎖側の肺 は3週後には上葉全体にわたつて出血をみると報告し, 酒井 ${ }^{29)}$ は一側上り炭末，他側上り正常空気を吸引せる そ炭末を吸わせた側の肺に炭末の沈着をみるのを観察

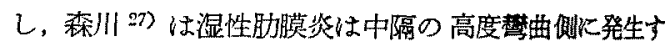
るものが多く、これらに中隔矯正術を行つて疾病を好颙 せしめ得たと報告しているが，これらの報告す片側通気 障害との因果関係を如実に物語つているるのである.

更に高橋(研) ${ }^{24)}$ は上気道に閉鎖があ九ば乎吸不足を

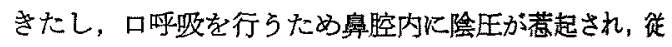
つて勫腔，鼻咽腔粘膜にらつ血をきたし，更に病原菌に 対する抵抗を減退せしめるとのへている，この場合，5 つ血といらことは一つの仮定であるとしても，気流の変 化に上つて炎症性病変の消長が考党られることは，本串 騟で証明し得たことであるから，高橋（研）のいら正常 ならざる鼻呼吸が多くの障害を㟟起しらるといら考方方 には，少くとも鼻中㢳禁曲が存在するが゙り，これ下同 意することができる，何故なら，すで代当教室で多く発 表してきた如く，奥咽腔炎と関連して消長する耳算科的 乃至内科的疾患の数々は, 当然のことながら鼻咽腔炎の 治療によつて，その治癒が促進されるすのであるが，そ

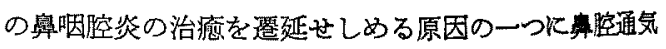
障害というむのが存在することが確認されたからであ る.

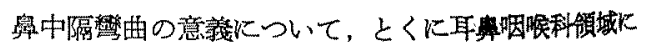
怙いては，古くから強調されているが，著者は祭抹票 本といら簡便な方法を駆使することにより，その中倩凸

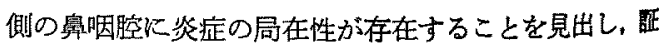
明することができた。鼻咽腔炎が重要な役割を果す痴患 であることが判明した今日，咽腔炎の一原因が究明さ れたことは意義あることと思われる。 


\section{井出 論 交 付 図 (I)}

鼻中隔譬曲症例の番咽腔淕抹上皮像

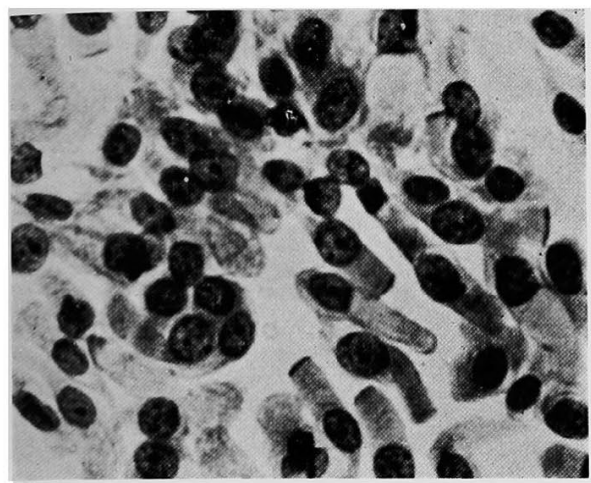

写真A 症例 1 高度第曲例の第曲側（凸側） 多数の線毛上皮細胞の槑離, 細胞質の一部 は膨化，空胞化などの変化を示す.

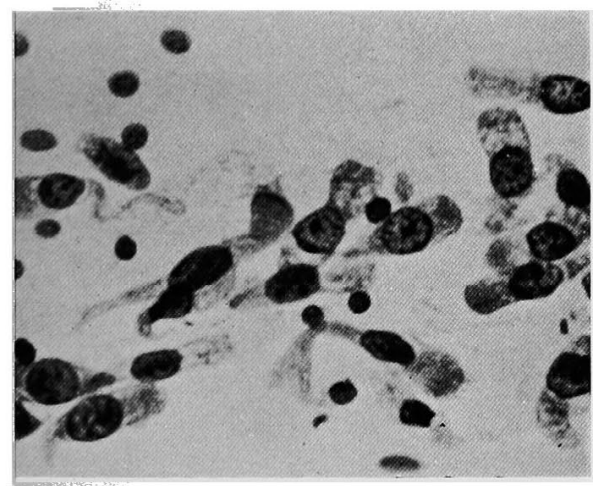

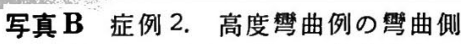

線毛上皮細胞は膨化，空胞化を示するの多 く，線毛並びに小皮縁を欠くものもある. 少数のリンパ球, 赤血球を混しててい.

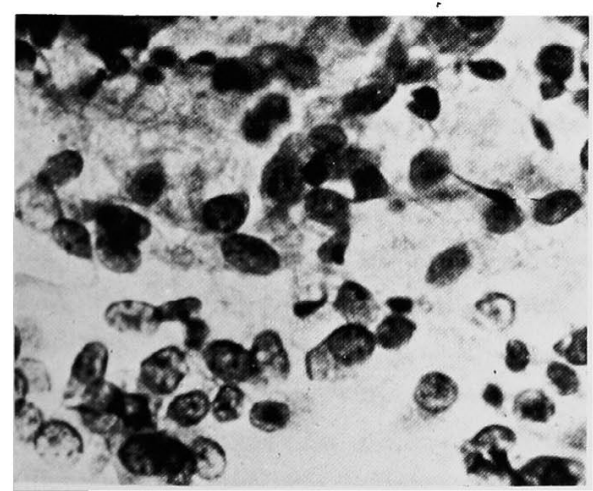

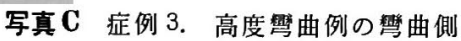

多数の上皮細胞は, 細胞質の膨化著しく， 変形高度, 染色性の低下を示し, 線毛, 小 皮縁を有するものはほとんど認められな い.白血球执よびリンハ球を混じている。

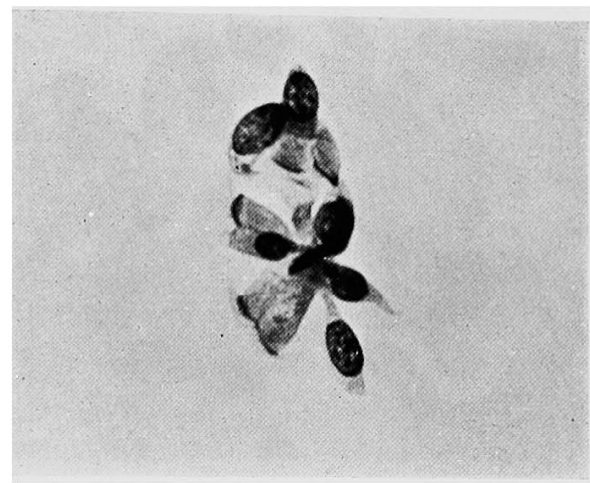

写真 $\mathbf{A}^{\prime}$ 同左, 非警曲側 (似側)

比較的正常な, 少数の線毛上皮細胞. 線 毛もみられる。

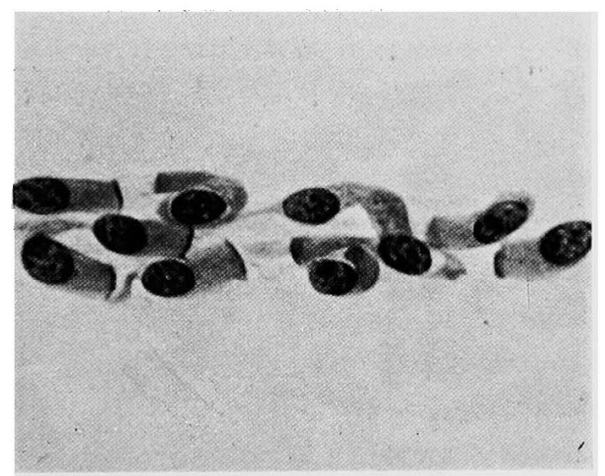

写真 $\mathbf{B}^{\prime}$ 同左, 非䑪曲側

細胞質の軽い膨化がみられるが，比較的 正常に近い上皮細胞。

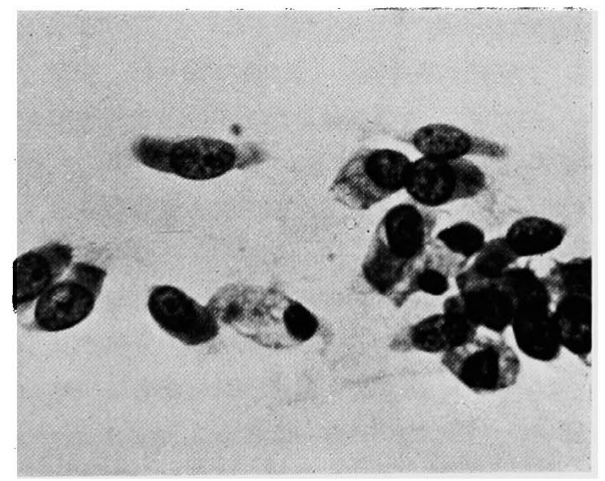

写真 $\mathbf{C}^{\prime}$ 同左, 非䇾曲側

III型の線毛上皮細胞に混じて少数の否細 胞をみる。上皮細胞の一部は膨化, 空胞 化を示して，線毛，小皮縁が消失してい 万。 


\section{井出論交 付図 (II)}

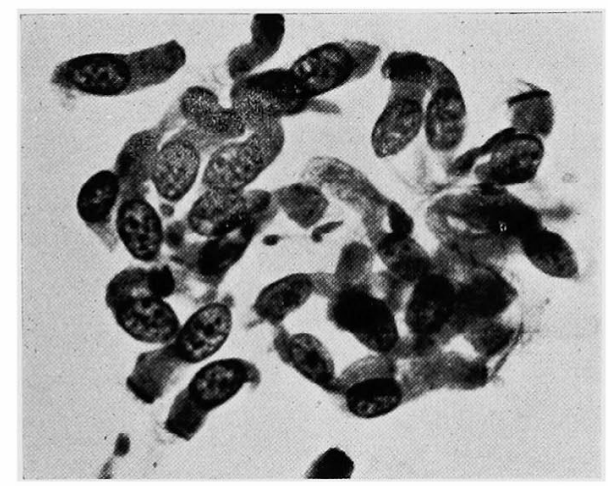

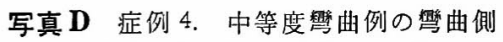
比較的正常に近い線毛上皮細胞，線毛も認 められる.

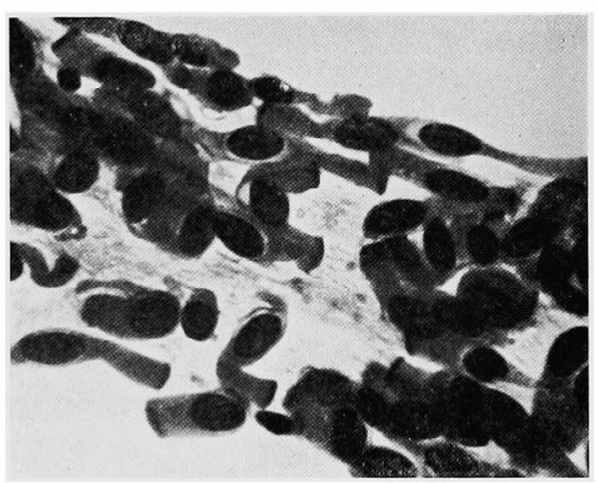

写真 $\mathbf{E}$ 症例 5. 中等度警曲例の繁曲側 多数の線毛上皮細胞の例離, 变形は比較的 軽度。小皮緑，線毛を有するもの多い

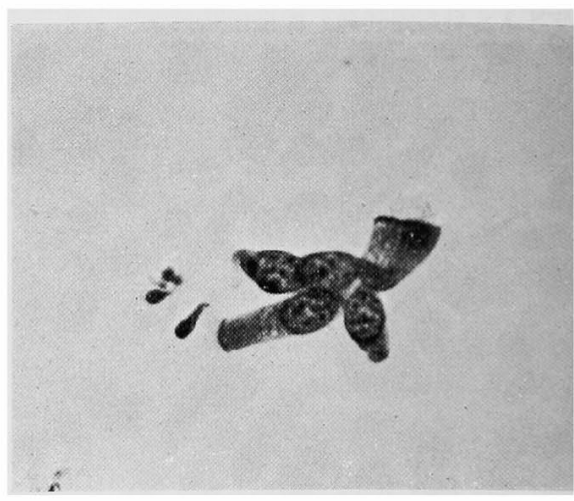

写真 D' 同左, 非察曲側

比較的正常に近い線毛上皮細胞（I 型）. 多数の線毛を有する. 䟝離数は少い

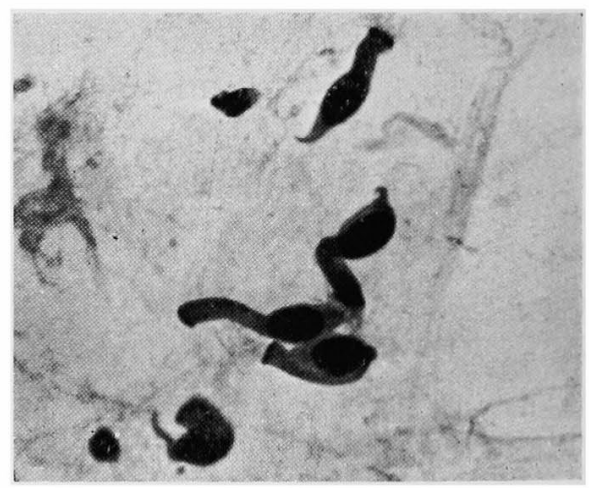

写真 $\mathbf{E}^{\prime}$ 同左, 非禁曲側 比較的正常に近い線毛を備光た線毛上皮 細胞. 
VI. 結 論

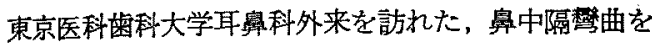
有与る症例 160 例（高度曲 44 例，中等度彎曲 58 例，

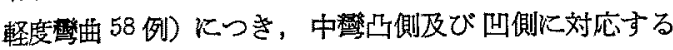
喵咽腔部より，別々に塗抹標本 (Papaincolaon 染色) を作製し，その涂離細胞像を比較検討し，臨床症状とも 昭合して次の結論を得た。

（1）奥閍は禁曲が高度になる程，その凸側で強く，

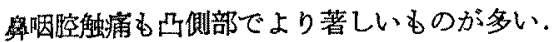

（2）奥中隔凸側に対応する 奥咽腔部は，他側に比し て, 線毛上皮細胞の剝離数が著しく多く, その変形程度 む高度のものが多い.

（3）盃細胞，白血球，リンパ球の出現も，凹側鼻咽 腔部に著しいるのが多い。

（4）上記稩胞中，最も著明な左右差を示するのは， 線毛上皮細胞の彔離数である。

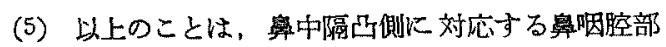
奻他側に比して，炎症の程度が高いといらことを示㛺す る。

\section{窑考文献}

1) 堀口申作，井出靖夫：奥咽腔炎の塗林細胞像一特 飞触痛上上皮像の関係について，日耳鼻，67，(2). 昭39.

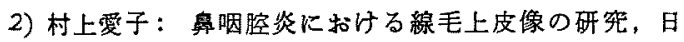

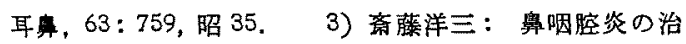
热過程の臨床的並びに剔離細胞学的研究, 日耳鼻, 66:

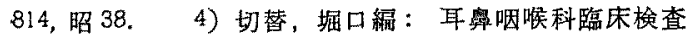
法, 昭 33.5 ） 日煟全第 2 巻, 昭 30 .

Zwaademaker: Die Untersuchungsmethoden der Nase und ihren Nebenhölen Haymann' Handbuch d. Laryng. u. Rhino. Bd. III 217, 1900. 7) 山胳

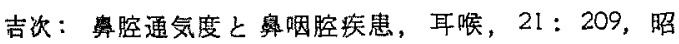
24. 8) Sternberg, H.: Beitrag zur Physiologie und Pathologie der Schleimhaut der Luftwege $I$. Die Veränderung der Nasenschleimhaut bei ausgeschalteter Nasenatmung Zschr. f. H.-N.-u. O-hkd 7 : 432, 1924. 9) Dixon, F.W. et al: The nasal mucosa in the laryngectomized patients Ann. of O.R.L. 58: 535, 1949. 10) Hilding, A.: Experimental surgery of the nose and sinus Changes in the morphology of the epithelium following variation in ventilation Arch. Otol. 16:9 (July), 1932. 11) Oppikofer, E.: Beiträge zur normalen und pathologischen Anatomie der Nase und ihrer Nebenhöhlen
Arch. f. Laryng. n. Rhin. 19: 28, 1907.

Proetz, A.W.: Applied physiology of the nose St. Louis, Annals publishing Co. p. 199, 1946.

Schall, Le Roy A.: The histology and chronic inflammation of the nasal mucous membrane Ann. of O.R.L. $42: 15,1933 . \quad$ 14) Schiefferdecker P.: Histologie der Schleimhaut der Nase und iher Nebenhöhlen von Prof. P. Schiefferdecker in Bonn Handbuch d. Laryng. u. Rhino. Vienna 1896. 15)

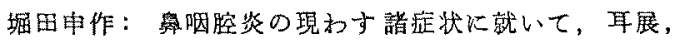

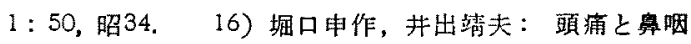
腔炎，日耳鼠，65：1360，昭37。17）堀口申作，俩藤

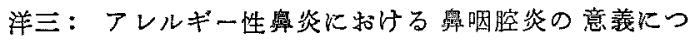
いて，日耳鼻，65：1368，昭37。18）堀口申作，大久 保保：鼻咽腔炎と所謂起立性調節㜔害の臨床钼察，小 坚科，3:611, 昭37、19）堀口申作，藤森克男：フ

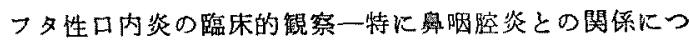
心七一，耳喉，35: 141, 昭38。20) 堀口电作，他：

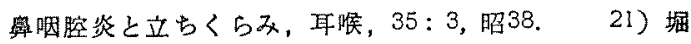

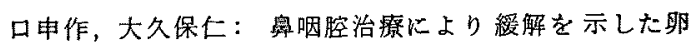
白, 牛乳アレルギーと潾槽濃漏の 1 症例, 耳㮢, 35:

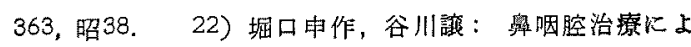
り綏解示したリウマチ棁疾患の1症例，耳唤，35： 365, 昭38, 23) Proetz, F.W.: Air currents in the upper respiratory tract and their clinical importance Ann. of O.R.L. 60:439, 1951， 24) 高橋研三：摱 性肥厚性與炎，高狭鼻，副蛽炎の主なる病理及び治療 法, 日耳舞, $24: 404$, 大7, 25) 高橋主: 鼻中隔上 部譬曲症の臨床的意㼁，耳㬋，19:111，昭21。26)

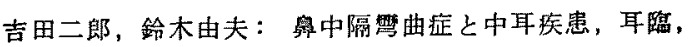
$43 ： 8$ ，昭25，27）森川護三：鼻中隔慗曲之胸部疾

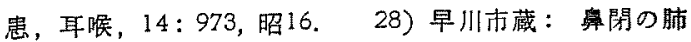
に及ぼす影響についての奏験的研究，满医誌，28：1， 昭13.29）酒井由夫：呼吸器内における気流の研究,

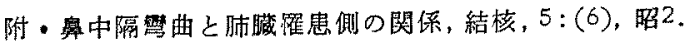

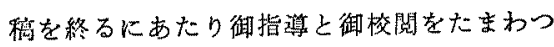
た恩師堀口申作教授ならびに本学溁聴研病理秋 吉正豊教授に梁く感謝します。

な和本諭文の要旨は昭和38年4月，第64回日 本耳咽喉科学会総会（大阪）で発瑟した。

（原稿到着 $=$ 昭和 38.7 .17 日） 